\title{
A PHILOSOPHICAL INVESTIGATON INTO AFRICAN VALUES: TOWARDS AMELIORATING THE AFRICAN PREDICAMENT
}

\author{
Charles C. Nweke \& Chukwugozie D. Nwoye \\ http://dx.doi.org/10.4314/og.v12i s1.6
}

\begin{abstract}
To say that Africans have been termed inferior beings by the racist philosophy of some western Europeans is to say a known fact. To say that most Africans have consciously or unconsciously assimilated that inferiority label is equally a cleat fact. To argue that colonization and Christianization of Africans by western Europeans left negative effects on the psyche of Africans is to say nothing but the truth. Due to the combined forces of colonization, Christianization, Islamization and chiefly slave trade, etc., with their attendant ills resulting in the inferiority complex ofthe African, the African seems to have lost confidence and consequently, looked down on her traditional values, hence, devaluing those cherished and veritable autochthonous values that have the power to better her conditions. In this piece, through the method of philosophical investigation, a case is made to the effect that, in the devalued African values, among others, lie solutions to Africa's predicament.
\end{abstract}

\section{Introduction}

It is a common saying that Africa is in quandary. It is on the lips of both Africans and non-Africans that Africa is backward, lagging behind in everything and summarily underdeveloped when compared with other nations of the world. In mass media, both the print and electronics, especially of foreign extraction, it is an easy perception that Africa is a cesspit of moral decadence where rapping, women battering, human trafficking especially child trafficking, baby factories, ritual killings, etc., are the order of the day. It is said that Africa is a cesspool of ethnic/tribal clashing to cleansing, teens used as child soldiers, where leaders prefer to spill innocent blood instead of relinquishing power when it is time, where religious intolerance and fundamentalism distort thinking and actions. It is a continent diseased and poverty-stricken, and more so, incapable of 
helping herself. It is a continent portrayed to be dark just as its colour is indeed black. The question becomes, is the continent of Africa really dark and its future bleak as portrayed? Again, and fundamentally too, what gave rise to such portrayal? It is the contention of this paper that Africa is not totally as portrayed above and that Africa has the possibility of brighter future. Also, the cause that gave rise to the impetus to describe Africa as in the foregoing is primarily occasioned by external factors instead of internal ones. By external factors we mean slavery and slave trade in Africa, partitioning of Africa, colonialism, imperialism and its corollary of capitalism that has exploited Africa to its marrow; all by the Europeans. On the other hand, internal factors, refer to the argument that Africa's problem is chiefly by Africans themselves.

In this discourse, it is important to point out the fact that the nature of the topic propels one to give a representation of African countries as to which countries in Africa show more or less inferiority complex due to western incursion. However, Nigeria is adopted as a case study here since it seems to represent all that is needed to drive home our point. It is in this regard that the words of Bedford Nwabueze Umez come in handy:
Although a perfect representation of African countries cannot be made using one country, I decided to focus on Nigeria to make my point. Nigeria is, in many aspects, a typical African country. It suffered slavery; it was subjected to colonial rule; it achieved political independence (1960) around the time so many African countries did; it is faced with the task of welding into a nation a variety of differing people. Besides, Nigeria is, by population, the largest Africancountry.

It is in line with the contention of this paper that this discourse is patterned as follows: section one elucidates the sources that propel Africa to be tarred with the negative brush especially by the culprits themselves; section two is concerned with the investigation, philosophically, into African values with the concomitant claimant that in those values lie, primarily, the path to Africa's brighter 
future, over and above, borrowings from other value systems; section three summarily and reflectively concludes the discourse.

\section{African Predicament: Sources}

Before sourcing the causes of African predicament, it is imperative that one sees Africa in her hey days before things started falling apart for her by external factors. From the picture painted above of Africa in the introductory notes, one may easily forget or not know at all that Africa was once quite important for the emergence and development of mankind and, greatly too, for the actualization of mankind's civilization. Her achievements in the history of man's civilization are so immense and unforgettable that Oguejiofor argues thus:

Scientists no longer dispute that Africa is the cradle of the human race and its evolution to the stage of homo sapiens many hundreds of thousands of years ago, and before the beginning of the Neanderthaal period in Europe. Africa was also the cradle of the technological evolution of humanity from the invention of wooden and bone tools to the momentous advance into the stone-age. "It is important to note," writes ObafemiAwolowo, "that the use of stone tools was a technical revolution among primitive people of the old, middle and New stone age, and that, in this revolution, Africa was clearly in the lead." With time, neopaleolithic Africa advanced into the era of farming, and pastoralism and thence into the iron-age. By 600BC, it was able to produce what has been described as "perhaps the best steel in the world of the time, and certainly equal to or even better than the steel produced in early modern Europe (24).

Continuing on his apology, Oguejiofor maintains that African continent played host to ancient civilizations like Egypt, Kush, Napata and Meroe, Nubia and Axum. In the heyday of the named civilizations, African continent was abreast with the rest of the world 
on the journey to civilization. That the northern region of Africa had first the flourishing Christianity that gave rise to people like Augustine, Origen, Athanasius, Clement of Alexandria, and host of others. Equally, that when the expansionist Islam eroded the achievements of Christianity in its northern region, also the region became a good platform for Islam buoyancy and its subsequent spread south of the Sahara.

From about the 7th century AD down to the modern times, the continent could boast of such states and empires as Ghana, Mali, Songhai, Akan, Mossi, Oyo, Benin, Hausa, Congo, Ouadai, Darfur, Funji, Ethiopia, Zimbabwe, and so on. Many of these states and empires, like all human and time-bound institutions followed, first virile stages of evolution, then reached their apogees and declined, long before the continent was to face the greatest horrors of its history. Others reached the threshold of the modern times, only to be overwhelmed by the tide of history which they could not resist and the force of which was boosted both by the special context of their existence, and by their unwitting participation in that history (Oguejiofor 24-25).

With the picture of African past painted thus, what then eclipsed that glory? How is it that today Africa is associated with everything negative by especially the western world to the extent that Africans themselves are buying into such negative outlook? How are they buying into such negative outlook?

... those I looked up to, namely, my mentors, educators, and leaders were busy teaching me and other youths, probably inadvertently, to feel inferior and remain inferior. Essentially, I was taught, just as many youths in Nigeria are being taught today, to feel inferior and develop low self-esteem. Here are few examples. I was thoughtlessly taught (and children are still being thoughtlessly taught today), 
that "oyibobundimuo," (white men are naturally spirits)," "oyibobuagbara," (white men are wizards by nature), and "America iluoba" (which suggests that white man's country is naturally the land of kings). Similar phrases such as "danbature," (which implies that white men are by nature civilized), and "or buter" (which symbolizes the natural lead of white men) are very common all over Nigeria.

I was thoughtlessly taught (as children are still being thoughtlessly taught today) that almost anything "black" is inherently evil. In fact, to our "educators," it is perfectly okay to use the word, "black" (the ascribed name to people with African decent), to describe evil. In accordance with this teaching, a bad person is the "black sheep of the family," and should be "black listed." In accordance with this teaching, illegal market is "black market" (as if only black people do business in such market). In according with this teaching, Satan (no one has ever seen) is "black" in color. In fact, to our "educated" teachers, frequent use of "black" to describe evil demonstrates a mastery of the "Queen's English," deserving an "A" in English essay composition. What an education! It is a pity! (Bedford NwabuezeUmez)

As earlier stated, external factors are largely the causes of African predicament. By external factors is meant slavery and slave trade in Africa, partitioning of Africa that gave way for colonialism and neocolonialism and the subsequent imperialism that resulted in capitalism's exploitation of Africa. Before giving evidences on how the above named factors were and still responsible for Africa's predicament, it is imperative that one points out that it is the disadvantage of political fragmentation characteristic of ancient Africa that opened the door for European incursion into Africa in the first place. In comparison, most African political organizations were small and sometimes minute in their territorial expanse. Noteworthy 
is the fact that only about thirty percent of Atlantic Africa was occupied by state with surface areas ranging more than 50,000 square kilometers, and that more than half of them were manned by mini-states accommodating between 500-1000 square kilometers. As a typical example, in Igboland, political organizations were limited to single autonomous towns and villages; hence, the veracity of the saying that political fragmentation was the standard in Africa. Sequel to the above, it is maintained that: "This system made territorial expansion a non-profitable venture. Be that as it may, political fragmentation was a major facilitator of one of the darkest blight in African history: the trans-atlantic slave trade."(Oguejiofor 25-26) That is to say, it opened the door for slave trade in Africa in a peculiar way. It is on account of this that Oguejiofor opined as follow:

What is peculiar about the phenomenon of slavery in Africa is not its mere presence, but the fact that it was in Africa alone that large sections of the population of a whole continent were, until well into the nineteenth century, dispersed in millions as slaves to distant parts of the world. The African slave trade has therefore been very aptly described as the 'most iniquitous transaction in human history.'(26)

This particular phenomenon carried with it baggage of disadvantages to Africans. The slave trade implanted in Africa the atmosphere of insecurity, bloodshed, and militated against the conditions that could guarantee peace in Africa. The millions of people carried away in their numbers signaled terrible decimation of the productive capacity, especially when the target of this evil trade was the youth, those at the prime of their lives. Equally, wars targeted at gathering slaves and other busts meant untold disruption of economic and social life. Therein existed no conducive atmosphere for peaceful existence much less development of any form, as a result. Slave trade bequeathed fear, social insecurity, violence and political instability. In sum, "Slave trading aided in the industrialization of the West, and sent Africa further down into the valley of 
underdevelopment. It is reported that when the first Europeans came to the West coast of Africa, the continent was comparable, at least in part, to Europe."(31)But today, the reverse is the case. Africa trails behind Europe, the U.S and even many countries that were then categorized as underdeveloped with Africa.

Following closely on the heels of slave trade in Africa is the phenomenon of partitioning of Africa. "Arranged and given 'legitimacy' by the Berlin conference of 1885 , partition meant a further round of destruction, neglect and deterioration of things African - art and craft, language and oral literature, social, political and religious institutions."(Oguejiofor 32) It had the debilitating effect that "With the partition of Africa, different ethnic groups and nations suddenly became parts of the same political entities without any regard to their history, religion, culture, or experience."(33) And this is where the deed was done. Partitioning of Africa gave rise to the issues of ethnicism and religious bigotry. In Africa today, Africans are so ethnic and religious conscious that every issue is seen along those divides. Hardly can an average African express an opinion or feelings about an issue without a tincture of ethnic influence and religious loyalty. In Nigeria, for instance, the Fulanis are at logger heads with the Hausas, Ndigbo often accuse the Yorubas of treachery, and often there are clashes between the Fulani cattle rearers and the Tiv people, to mention but a few. In Nigeria still, among people of the same ethnic group, there are conflicts, clashes among brothers and sisters because of different religions they belong to individually. Within a particular religion, brothers and sisters of the same family, often find themselves in strained relationship owing to different sects found in that particular religious affiliation. This situation is found in almost all the countries of Africa if not all. The phenomenon of religious chauvinism supersedes that of ethnicism in terms of causes of African poor outlook among the comity of nations occasioned by the European incursion into Africa. This is because within a particular ethnic group, religions abound with it divisive feature as it has come to characterize Africa. It is due to the ontological importance, allinfluencing and Being-to-being-binding nature of religion, in man generally, that made Achebe to summarize the destructive nature of European incursion into Africa, in terms of religion, thus: ". Now he has won our brothers, and our clan can no longer act like one. He has 
put a knife on the things that held us together and we have fallen apart." ( 141) That is to say, Europeans have broken that that binds Africans together, that source of cohesion, rallying point, the binding force among Africans. And true to Achebe's saying, the west has used that successfully to the detriment of Africa's unity, nay, and development. Why? It is because of the nature of religion. To appreciate what one is saying here, it is good to look into the phenomenon of religion and understand why the colonial masters saw it as the necessary hotbed for Africa's disunity and perpetual dependence, then the ugly picture they paint of Africa. A case of giving a dog bad name and hanging it by it! Just like philosophy, the concept religion defies unanimously one accepted definition. In highlighting this difficulty and articulating reasons for it, Metuh says:

Religion is a very elusive concept to define. This is partly because the object of religion for the most part is invisible and spiritual beings who are not subject to observation and are conceived in different ways by different people. (13)

The difficulty in articulating what religion is notwithstanding, one can say that religion is occasioned due to man's limitedness in the face of daunting experiences, challenges. As a result, man sought for an anchor on a Being higher than man and this resulted in many expressions of this Being corresponding to different host environments. In line with the above, Madu cites Watch Tower observing that:

During the thousands of years of mankind's history, man's search for God has led down to many pathways. The result has been the enormous diversity of religious expressions found worldwide, from endless variety of Hinduism to the Monotheism of Judaism, Islam and Christendom and to the oriental philosophies of Shinto, Taoism, Buddhism and Confucianism. In the other vast 
regions, mankind has turned to Animism, magic and spiritism. (17)

Seen the nature of the phenomenon called religion in the foregoing, it is good that we attempt the definition of it. From etymological angle, religion is derived from the sources below.

1. Religando: meaning refattening up or binding back. This is the opinion of Lectantius because for him, religion expresses a situation in which God overpowers man, thereby binding him (man) to himself.

2. Religendo-relegere: to re-read. This is the opinion of Cicero, since for him, religion is the fruit of assiduous study or meditation on divine things.

3. Re-elegere: re-election, in which St. Augustine sees the idea of re-election, by which God chooses to re-establish man in grace after man had lost former grace by sin.(Madu 18)

Apart from the etymological angles of religion, religion can also be seen in other various shades:

i. Union or community with God. This community or communion with God arises from the ineffable condescension of love on God's part and the response of love which this condescension invites or demands on our part. Thus, religion in this sense is the bond uniting us with God, through the God-formed life of grace. The response is therefore an act of adoration.

ii. Religion in the rather restricted or technical sense designates the cult or worships rendered to God whether it be public or private.

iii. Religion can mean a community of worshipers. In this sense, it is the community of those who have the same faith and cult. Thus one 
may ask, which religion do you profess? Christianity, Islam or Hinduism?

iv. The canonical use of the word. The church in her canon law uses the Latin word "Religio' to designate religious orders of communities or societies. We speak of "entering religion", life in religion, religious life, religious men and women. In Christianity, religion in this sense means a community in which Christians come together to consecrate themselves to God in a special way by means of a public act (vow). They vow to live a religious life of Union with God. (Madu 18-19)

Seeing these shades of meaning of religion, Madu in the words of Arinze attempts definitely the definition of religion by summarizing it as being subjective and objective. Subjectively, religion is the ultimate consciousness of reliance on a transcendent being and the very proclivity to show cult or to worship. Objectively, it is a concatenation of truths, laws and rites by which man submits to the transcendent being. For Madu, in this wise, religion signifies man's moral relations with God, relations of created beings to creator. In it, man internally and freely acknowledges his reliance on God, and externally shows acts of cult either personally or collectively. Religion, as it were, is the strongest element in man and pulls most likely the highest influence in man. Hence, it exhibits itself in beliefs, ceremonies, rituals and officiants like the priesthood (19).

According to C.O.T Ugwu: "Religion could be defined as faith and practices involving the relationship between mankind and what is regarded as sacred."(2) Again he says: "Religion generally includes the belief in the supernatural and a code of ethical behavior." (2) E.B. Tylor in his minimal definition, sees religion as the belief in spiritual beings. (qtd. in Metuh, E.I. 18) For Encyclopaedia of Religion, it is seen as:

The outward act or form by which men indicate their recognition of the existence of God or gods having power over their destiny, to whom obedience, service and honour are due; the feeling 
or expression of human love, fear or awe of some of superhuman and over-ruling power, whether by profession of belief, by observance of rites and ceremonies or by the conduct of life. (250)

Having seen the unfolding discourse on religion so far, a brief look at the two major theories of the origin of religion follows. According to Madu, scholars of different bents have adduced variant origins starting from the well known intellectual philosophical theories like Kant's, to the emotional sentimental theories of Schleiermaher, Jacobi or in traditionalism of Lamennias to explain the origin of religion. (22)

The intellectual theories stem from man's curiosity to explain the mystery of the universe. Abstractly, man with his intellect reflected on the ultimate cause of all things. Although this ultimate cause is invisible, the reflection on it is borne out of experience of the things observable in nature. Man's investigation of the universe therefore forms the starting point of his basic cosmology on which he came face to face with the insoluble or the incomprehensible, the mystery of God. Philosophically and logically, thinkers began their speculations in this regard with the universe as a phenomenon of intelligibility and arrived at the unflagging belief that there is indeed a Being and not beings responsible for the being of the world. Thus great thinkers took this Being as Supreme in relation to other realities whatsoever. It was under this backdrop that man started to posit the whats, hows and whys of things. The intellectual theory also explains the "invention of God" hypothesis, a god who would take care of the hidden sins of man of which the legal prescriptions of the state cannot unravel. (23)

On the side of emotional theory: 
Experience shows that man is surrounded by forces of nature upon which he does not know how to control. Also, some important regularities are clear to us e.g. the rhythm of day and night, the march of the seasons, but there are also inevitable contingences which may arouse fear, e.g. the crops may be scanty, the rains late, the women barren. Thus the emotions aroused in all these simultaneously demand an outlet. Thus great hopes and great fears must express themselves in actions which eventually become ritualized. Ritual is the primary fact of religion for through it men's fears are allayed and confidence restored. The rites are then explained by myths, creeds, dogmas concerning spirit forces, gods and demons. (24)

There are other theories about the origin of religion but, basically they are reduced to the intellectual and emotional origins. Others are simply modifications of the basic two above.

Having seen religion in details, that is, the nature, definitions, theories of origins of religion and the import of religion, it can be summarized with Ugwu that: "Religion, therefore could be defined as faith and practices involving the relationships between mankind and what is regarded as sacred. Religion generally includes the belief in the supernatural and a code of ethical behavior."(2)

With the above elucidations on religion, we can re-assert with the author that "Religion, as it were, is the strongest element in man and most likely the highest influence in man. Hence, it exhibits itself in beliefs, ceremonies, rituals and officiates like the priesthood." It is in the understanding of this reality that the colonial masters through their teleguided and skewed form of education in Africa sowed the seed of discord that unsettles Africans till date. And this is so penetrating and endemic that one hardly encounters Africans discussing without such discussions affected by religious sensibilities. And this has uglily snowballed into religious fundamentalism as is witnessed in Africa today. The phenomenon of religious fundamentalism and their nefarious, atrocious activities are palpably felt almost everywhere.The threat of religious fundamentalism is nothing new in Uganda; its government has been 
dealing with the Lord's Resistance Army insurgency that seeks to establish a theocracy guided by the biblical Ten Commandments since 1987. The LRA, composed mainly of forced child-soldiers, has been accused of abductions, rape, sexual enslavement of young girls and murder of innocent Ugandans. (The Bait of Christian Fundamentalism in Africa)Another one is a Sunni group founded in Algeria. It is highly responsible for the renewal of Islamic insurgency in North Africa with the set goals as the overthrow of the Algerian government and the enthronement of an Islamic state instead. With its merger with al-Qaeda, it has become internationalized and with its name as Al-Qaeda in the Islamic Maghreb. Its activities went beyond the Sahel to include attacks in Mauritania, Mali, Niger and Chad, to kidnapping of various European tourists in North Africa (The Bait of Christian Fundamentalism in Africa).

In Nigeria, it is Boko Haram. Boko Haram in Hausa language means that "Western education is sinful", as such, its agenda are opposition to any interaction with the West and rejection of modern science with the argument that it is against Islamic teaching. (The Bait of Christian Fundamentalism in Africa).In Somalia and the Horn of Africa is found Al-shabab. Sequel to their hard line ideology, Al-shabab's list of enemies includes the Transitional Federal Government of Somalia (TFG), the United States, the African Union itself and Kenya. (The Bait of Christian Fundamentalism in Africa). According to Binoy Kampmark, in Mali is found the newest religious fundamentalism that emerged in 2012 to hijack the control of northern Mali, Ansar Dine. Their activities have been vicious - banning of music, destroying Sufi shrines in Timbuktu. For the leader of this group, SalafistLyad Ag Ghaly, “... the word of God does matter - a great deal. Long gone is the man who used to smoke and keep company with the musicians from Tinariwen.' This has made Africans to be perpetually divided among themselves, hence, the ills associated with it has given the impetus to portray Africa in terribly negative light. It is hard for African leaders to agree on common course of action without religious sensibilities often times undermining it.

Another point in external factors causes of Africa's predicament is the issue of colonialism. Associated with colonialism is the phenomenon of cultural alienation. That is why it is 
maintained that: "... the problem of cultural alienation which besieges most Africans today is almost directly linked with the colonization of the continent." (Oguejiofor 41)

The attempt to create the new Africa in a new outfit of a modern culture and civilization implied the introduction of education. But the modern education that the first Africans received was completely Europe-based. History meant the study of European history. Geography was the geography of Europe and North America. Language was no other than English, French, Spanish and Portuguese. The new African that emerged as the end product of acculturation was thus tailor-made not only to neglect but also to despise his own culture. The project of reeducation was by far the most successful of all colonial projects. The African, not being backed by a culture and civilization resilient enough to resist the onslaught, swallowed his indoctrination without reserve. The sign of modern learning, for him, became how Europeanized he was, that is, how much he was accustomed to what is foreign, and how estranged he was from his own milieu. The concept 'foreign' quickly acquired an added meaning, 'superior.' Fluency in the languages of the colonizers became a respectable mark of learning, and the acquisition of such languages was accompanied by the forgetfulness of one's own native language. In the sprawling cities of Lagos, Kinshasa, Nairobi and Dakar, many children of highly educated parents are unable to speak native languages, and their parents are able to exhibit the phenomenon as a sign of high social status. (Oguejiofor 42)

With the disadvantage of cultural alienation as a result of colonialism came further worst problems from cultural alienation itself. Culture is generally 
seen as the total way of life of a people. With the project of re-education of Africans, the colonizers hit at the sucker punch against Africans. The worst form of enslavement, mental slavery. With reeducation in the form of supplanting everything African with everything European, it meant the throwing away of African culture with the veritable, cherished values therein. Africans started to look down on their source of identity which is their respective languages, and more so, values in their culture. Their mode of dressing, manner of eating, way of greeting, etc., were all meant to be despised and that of their colonial masters to be embraced. Europe became the model for Africa. At the end, Africans became deracinated, hence, Oguejiofor argues: "Left in the lush of modernization the alienated African is without a past, without a present and without a bright future."(43)

Following colonialism and neo-colonialism is the European imperialism with its capitalistic tool of exploitation of Africa. This capitalistic exploitation is seen today in the form of multi-national corporations siphoning the wealth of Africa through shares in companies. Also, the insistence by the west that Africa should operate free market economy is an evidence of the intention to keep Africa down. The aids, grants, loans, etc., given to Africa through financial institutions like International Monetary Fund and World Bank have proven to be more defective than effective to African development (Rodney184-208).

The cumulative effect of the foregoing external factors spear headed by slave trade had the indelible imprint of inferiority complex in the psyche of the African. Having been conquered! Referring to this issue of inferiority complex, Ayittey says: "It was probably this, rather than the physical and economic damage of the slave trade, that wrenched the heart from the inner psyche of blacks and assailed the very cultural soul of their existence.'(qtd. in Oguejiofor J.Obi. 46) Pinpointing at the devastating effect of inferiority complex on the psyche of the African, Oguejiofor writes: 
With this state of mind, the will for competitive struggle is whittled down to the lowest ebb. With loss of confidence in his system and in himself, the worst in man is likely to surface." (48) Summarily, he argues:

The most disturbing and the most ingrained aspect of the African predicament is therefore the psychological trauma which has given rise to a deep sense of inferiority. The average African does not believe he is, as a human being, equal to the rest of mankind. Most African intellectuals who should know better do not believe that their sometimes sad situation is the result of a given context. They do not believe that their race, their continent, their nation would have been different if the cumulative circumstances under which they evolved were to be different. The self-doubt of the present day African is immense. (48-49)

Sequel to the inferiority complex, the African has almost thrown away everything African, including African values, and swallowed everything western lock, stock and barrel. The question then becomes, what is the African to do in order restore his confidence in spite of the European incursion that left him with loss of confidence, inferiority complex, resulting in poor perception of his being, existence by the other?

\section{Restoration in African Values}

One may ask, how can the African, in the face of the intimidating scientific and technological achievements of the west, claim to be equal with them, and when will he match such achievements? The African must reassure himself with the fact that, in history, his forebears were the envy of the west because of their numerous feats; hence, Africa is recorded to be the cradle of civilization. He should not go sorrowing perpetually on the incidence of slave trade, the conquest. He should start building confidence in himself with the fact that all the empires of this world once reigned but now no longer reigning and Africa is no exception. He should take pride in the fact that the raw materials used by the so called developed 
nations were sourced from the continent of Africa. And that he can match and even surpass his western counterparts in terms of science and technology if African leaders can gather their acts together by providing the needed conducive environment and stop being stooges to the western powers. The achievements of numerous Africans like, Philip Emeagwali, scattered all over Europe testify to this. With the confidence built, the African must do the needful by looking inwards to excavate those values that distinguish him from the rest and are capable of giving him the wherewithal for development and subsequent acknowledgement and appreciation by the rest of the world. These are no other than the autochthonous African values. Do Africans have such, if yes, which values?

Over and above the racist informed denigrations that Africans have no rationality, it is good to reiterate the falsity of such premisses by saying that Africans share in that universal characteristic of humanity, with evidence from Ramose.

It is significant that one of the diplomatic successes of Kofi Annan, namely, securing an agreement with Iraq on the United Nations weapons inspection regime, has been attributed partly by many commentators to his experience in village quiet diplomacy in his native Ghana. This means that at times village diplomatic experience can save the international community from unnecessary war. (8)

The instance above proves the argument against rationality of Africans wrong and went further to point out the value of village quiet diplomacy of Africans meaning that conflicts are not always resolved ultimately by means of force or violence. It is a value of prolonged discussions among Africans which often is said to be tiresome but at the end of the day gives the desired result. This value that seems to be dying out in place of quick manipulations and maneuvers imbibed from the west should be revived to settle numerous conflicts ravaging African continent since the western styles of manipulation and maneuvers seem to paper over the conflicts instead of giving lasting solutions, settlements. 
It is a trite argument whether communalism is specifically and intrinsically African and Individualism that of the west. In this piece, we maintain that the two traits are found in every individual but some people are predominantly more of one or the other feature. Communalism is to Africa as individualism is to the west. This is explicit when C.B. Okolo in attempt to define an African person says: "...the African is not just a being but a being with, a beingwith-other..." (6) In a similar vein Mbiti writes, "the individual does not and cannot exist alone except corporately. He owes his existence to other people, including those of past generations and his contemporaries. He is simply part of the whole."(108) Embedded in this communalism is the twin values of solidarity and hospitality. The African man thinks in whole and not in unit, particular. He sees himself in the other and the other sees himself in one. In this seeing is the obligation of hospitality, that is, the ability to make another as comfortable and relaxed as possible. It is in line with the foregoing accentuation of solidarity in Africa that Iroegbu says:

To face the other person as person is to see oneself as a person. In my facing the neighbor, I do not face a thing, an object, but a person, a subject. There is here, no I its relationship not even primarily an I Thou relationship as Buber would hold. For us, it is a "We" relationship. The We involves communal solidarity of being. It is not mere inter-subjective dualistic and individual versus individual liaison. (359)

Affirming the corollary of hospitality to solidarity, Iroegbu writes thus: "in the $W e$ is seen the true community. In the community is seen the neighbor; the visitor; the stranger; the distant passerby. They are human and humane... Here, hospitality, kindness, fairness, sharing are at stake."(380) It is in the spirit of solidarity and hospitality that Ekei talks about the concept of Ogbe-enye (the community gives). (106-137) That is to say, the community comes to the help of the helpless, hapless. And this is reminiscent of the act of African where communities gather together to sponsor an indigent student once the capability for academic prowess is visibly 
demonstrated. It is in the same manner that a child is trained in one particular trade or the other by individuals or communities when the need is. But today, can that be said of Africans? By swallowing the value of individualism of the west, what is now the order of the day is, survival of the fittest. In the spirit of individualism introduced mainly by the capitalistic mentality, Africans have turned wolves to one another. In villages, people are afraid of giving alms due to the ugly experiences of untimely death of individuals who have tried to be of help in the real spirit of Africa tradition. This and like experiences, have contributed to African underdevelopment as those with capacities are not trained to use such for the general well-being of all. What is required therefore is revival of such altruistic attitude in order to reduce the ugly scenario of few being rich while the majority suffers. The twin values of solidarity and hospitality are urgently needed since the capitalistic mindset of competitiveness, individualism in isolation of the community has proven antithetical to African well-being. Africans need to counter the attitude of individualism with that of solidarity and hospitality for better Africa. In such a way, it will uplift the down trodden and corporate confidence will begin to emerge once again.

Excavated from the above is the African value of humanity/humaneness.

Most African languages have in their vernacular the saying which is synonymous with the following found in the Sotho language. The saying is that mothokemothokabatho. This means that to be human is to affirm one's humanness by recognizing the same in others and, on that basis, establish humane relations with them. Here it is botho understood as being human and having a humane (respectful and polite) attitude towards other human beings which constitutes the central meaning of the aphorism: mothokemothokabatho. (Ramose 111)

Expatiating on the import of the aphorism, Ramose says: 
This aphorism rest upon two organically interrelated philosophical principles. One is that the individual human being is an object of intrinsic value in its own right. If this were not so, it would be senseless to base the affirmation of one's humanness on the recognition of the same in the other and respect thereof. It is meaningful to state that to denigrate and disrespect the other human being is in the first place to denigrate and disrespect oneself only if it is accepted that oneself is an object worthy of dignity and respect. The other principle is that motho (a human being) is truly human only in the context of actual relations with other human beings. (111)

The value under discourse is quite important in the existence of Africans today owing to the spate of killings going on in Africa. Africans are dying in their numbers as a result of the quest for money due to the capitalist system that has come to define the continent. Africans in the quest for money engage in unprecedented ritual killings. Young girls have turned their wombs into baby factory (born and dump for others) all because of money. The religious fundamentalists have done the worst, all in the bid to get power and control the economy and the freedom of others. In retrospect, one may ask, has African traditional religion, the autochthonous religion of the African, the element of proselytization much less fundamentalism as it is witnessed today in Africa? The spate of social vices witnessed today is, arguably, as a result of foreign negative influences. These negative influences have turned Africans against the African traditional value of respect for sanctity of human life. There is little or no respect for the sacredness of human life among most Africans, hence, the gory scenarios people witness in Africa today. What of the killing of fellow Africans on the same African soil called xenophobic attacks? That is why the value of humanity/humaneness as described above is of imperative importance now in African existence in order to stem and eventually avert the terrible reality. This is because this value upholds the sacredness of human life. 
Similar to the above value is the value of sharing among Africans. According to Ramose, “...the principle of sharing has also been undermined in contemporary multi-party politics of Africa. It is essential to underline the fact that this principle covers the whole range of human relation. Thus it refers to the sharing of the joys and sorrows of life; of the goods of the earth and even the personal property we might have."(115) Arguing that the value of sharing and caring is indeed African, Ramose has this to say:

Sharing and caring for one another are basic tenets of African morality. Because of this most Africans who are employed continue to share their wages and salaries by way of caring for their unemployed kith and kin. This practice is evidently contrary to the philosophical outlook that provides their wages and salaries. According to this philosophical outlook, the wages and salaries are measured to suit the requirements of the employee and, if they are lucky, the members of their nuclear family as well. The wages and salaries are provided without due regard for the extended traditional African family. To stretch one's salary or wage beyond the boundaries of the nuclear family in the name of African morality is not only a severe strain but it is also a clear indication of a fundamental contradiction between African moral philosophy and western moral philosophy. (120)

With this insight, it is of paramount importance that this value should be revived and inculcated in the minds of contemporary Africans where few are super rich and the majority is very poor. The values of sharing and caring is needed in order to alleviate crimes as a result of poverty, like kidnapping for ransoms and also to uncover and utilize raw talents wasting and dying due to lack of needed sponsorships.

In today's Africa, the society is almost in tatters. In order to assert oneself, in the spirit of western avowal of freedom, most Africans have thrown the age long characteristic of Africa over 
board: respect for the elders. In today's Africa, in the language of equality of all mouthed by the west, the youth sees everybody as equal. They these days do, say, etc., bizarre things before their elders unlike the pristine African setting. These have got cosmic imbalance on Africans in that they have not successfully copied the western model and have not got a firm grip of their own value. It is the mantra among African elders today that things have spoilt. Things have spoilt because a vital element of social cohesion is missing. Respect for elders! Ironically, some of these elders seen mostly in African leaders have compromised and merited disrespect. Indeed, an elder that lies shamelessly, steals from others, live licentiously, have no regard for the taboos of the land, etc., is indeed prone to disrespect from the younger ones. It is like a vicious circle! However, a stop needs to be put to it by African elders, especially the leaders, living and leading becomingly so that the younger ones will follow suit. Again, Africans have not successfully imitated the idea of non application of corporal punishment on the offspring as the west will advocate and yet the age long practice of corporal punishment done by Africans is fast losing ground. Hence, most African children are losing direction. A similar point is the idea of old people's home, in imitation of the west. In isolating the old, young Africans lose the benefit of elders' words of wisdom and knowledge. They lose the knowledge of their history which is veritable way of one's identity. Africans are neither here nor there. There is need therefore to revamp that value of respect not only because of the psychological positive effect it has on human beings but because of that order, cohesiveness it breeds in the society. Africans should be proud to identify with their manner of bringing up children which has fostered cohesion and stability in their environment and not being anxious to satisfy the self acclaimed epitome of all values, the west.

The height of African predicament as a result of European incursion into Africa is the fact of inferiority complex. And this complex is an issue of the mind. The Europeans worked on the minds of Africans and kept them where they are today. To counter the current, the African should re-work on his mind. Hence, over and above, the foregoing traditional African values, there is the essential need for Africans to adopt a more radical and critical reasoning in their approach to issues of life. This attitudinal change calls for 
restructuring of educational system in most African countries. Curriculum planners should bring in elements of philosophy broken down to primary school level understanding so that African children will begin early to inculcate the spirit of critical thinking. In African universities where there is no philosophy department, the policy should be reversed so that philosophy department will be open in them for philosophy has that singular attribute of initiating critical thinking in human beings. Again, history of countries in Africa in their individual countries should be taught as well as the history of Africa as a continent so that Africans will be conscious of whom they are and what to be done. Both formal and informal education in Africa should be permeated with African consciousness in order to engender the attitude of more radical and critical thinking among Africans. The result of this attitude is that Africans will cease to see things from their particular ethnic/religious interests in their respective countries --which is the ugly consequence of partitioning of Africa-- but through the periscope of national interests after a thorough discussion devoid of inequality, lack of freedom and inimical manipulations. Likewise, on continental issues, this attitude adopted will help them see issues from pan-Africanic view points and not from individual countries of origin. The benefit of this attitude is that it will foster unity among Africans which has been lacking. In this unity, Africans can then tackle issues objectively without inclining to those divisive elements implanted the by west. Hence, this attitude will put paid to ethnic and religious divides implanted in the minds of Africans which have divided and beclouded Africans from reasoning beyond those thresholds till date, and as such, keeping them perpetually down. With this mindset, Africans can begin to untie themselves from the unnecessary apron strings of the Europeans who have put them in this terrible tight corner and turned around to describe Africa in the most unspeakable terms. It is in this way that African predicament can be ameliorated and turned into African betterment.

\section{Conclusion}

In this paper, we have x-rayed the African problems, predicament and made it crystal clear that Africa's current deplorable conditions are occasioned cardinally by external factors. However, to come out of it, Africans have to look inward for in their traditional culture lies 
fossilized, so to speak, primarily the values that will rescue them. This does not negate the point that Africa can still look outward for other salutary values since no culture lives and survives on its own entirely. No culture is pristine in the real sense of it! When the African values of village quiet diplomacy (rationality), solidarity and hospitality, humanity/humaneness, sharing and caring, respect for the elders, coupled with the attitude of more radical and critical reasoning are conscientiously and vigorously revived and imbibed by the African, indubitably, the portrayed bleak future of Africa by the culprits themselves can be seen to have, in the contrary, a brighter and greater future. 


\section{References}

Achebe Chinua. Things Fall Apart, (Harlow: Pearson Education Ltd, 2008) Emphasis mine, that is, the parenthesis.

Ekei J.C. Justice in Communalism: A Foundation of Ethics in African Philosophy. Surulere: Realm Communications Ltd., 2001.

Iroegbu P. Metaphysics: The Kpim of Philosophy. Owerri: International Universities Press Ltd., 1995.

KampmarkBinoy,

http://www.internationalpolicydigest.org/2013/01/15/the-mali-

intervention-france-islamic-fundamentalism-and-africa/

Madu J.E. Fundamental of religious studies. Calabar: Franedoh Publishers (Nig) Ltd, 1997.

Mbiti J. C. African Religions and Philosophy. London: Heinemann, 1969.

Merriam W. (ed), Encyclopedia of Religion. New York: Prentice Hall, 1980.

Metuh E.I. Comparative studies in African Traditional Religions. Onitsha: Imico Publishers, 1987.

OguejioforJ.Obi. Philosophy and the African Predicament. Ibadan: Hope Publications, 2001.

Okolo C.B. What is to be African? Enugu: CectaNig.Ltd., 1993.

Ramose M.B. African Philosophy through Ubuntu.Harare: Mond Books, 2002.

“The Bait of Christian Fundamentalism in Africa" 22 $2^{\text {nd }}$ May 2013. www.huffingtonpost.com/.../christian- fundamentalismafrica-b-93568

Ugwu C.O.T. Man and His religion in a contemporary society.Nsukka: Chuka Education Publishers, 2000.

Umez Bedford Nwabueze. "Educated" to Feel Inferior: "Will Africa ever Catch Up?"

$8^{\text {th }}$ July2015.http://www.raceandhistory.com/historicalviews/ $\underline{02112003 . h t m}$ 